\title{
The Potential of Denitrification for the Stabilization of Activated Sludge Processes Affected by Low Alkalinity Problems
}

\author{
Heike Hoffmann*, Tatiana Barbosa da Costa, Delmira Beatriz Wolff, Christoph Platzer \\ and Rejane Helena Ribeiro da Costa \\ Departamento da Engenharia Sanitária e Ambiental; Universidade Federal de Santa Catarina; Campus \\ Universitário Trindade; rejane@ens.ufsc.br; 88010-970; Florianópolis- SC - Brasil
}

\begin{abstract}
In this study, the problems provoked by nitrification of wastewater with low alkalinity were analyzed in a pilot sequencing batch activated sludge reactor (SBR). Decrease in pH resulted in disappearence of protozoa. Deflocculation of the activated sludge floc started below pH 6.5, resulting in enhanced effluent turbidity and loss of bacteria. Nitrification efficiency was affected below pH 6.2. The denitrification activity was not sufficient to keep up the $\mathrm{pH}$, due to a low C/N ratio of the wastewater. Based on alkalinity and ammonia concentration of the wastewater and the necessary denitrification rate to prevent operational problems, was developed a prognostic diagram. The applicability of this diagram was tested for the SBR with excellent results. The diagram could be applied to optimize the operation of wastewater treatment plants affected by problems with low alkalinity wastewater.
\end{abstract}

Key words: Alkalinity, activated sludge, nitrification, denitrification

\section{INTRODUCTION}

Brazilian environmental legislation contemplates an ammonium reduction down to $20 \mathrm{mg} \mathrm{NH}_{4}-\mathrm{N} / \mathrm{L}$ (CONAMA, 2005). To fulfill this requirement, only the nitrification of wastewater is necessary. The nitrification is the oxidation of ammonia to nitrate but ammonia has more harmful effects on natural water systems than nitrate. The activated sludge system is the most used treatment among the available systems to achieve nitrification. To guarantee nitrification, activated sludge systems need relatively large volumes and a sufficient aeration, due to the low growth rate of the nitrifying bacteria, and their high sensitivity against alterations of $\mathrm{pH}$, lack of oxygen, high organic loads and toxic substances and low temperatures (Nitrogen Control, 1993, Wolff et al., 2005).

An important aspect in nitrification in Brazil is the formation of acid as a side product of the nitrification, a fact that normally does not call much attention because in many cases wastewater is characterized by a sufficient alkalinity to keep the $\mathrm{pH}$ above of 7.2, a value registered as sufficient for nitrification (Von Sperling, 1997). But Brazilian wastewater, as the drinking water too, many times has low alkalinity. According to the definition (ATV-Manual, 1997), an alkalinity below $1.5 \mathrm{mmol} \mathrm{HCO}_{3}{ }^{-} / \mathrm{L}$ or $75 \mathrm{mg} \mathrm{CaCO} 3 \mathrm{mmol}$

\footnotetext{
${ }^{*}$ Author for correspondence
} 
$/ \mathrm{L}$ in the effluent is the limit in order to avoid operational problems in the treatment process, as deflocculation or destruction of activated sludge flocs. The $\mathrm{pH}$ can be stabilized with a continuous addition of carbonate (lime). A more economic solution would be the stabilization of the process through the use of denitrification. The denitrification process has the capacity to recuperate half of the lost alkalinity in result of nitrification (ATV-Manual, 1997; Von Sperling, 1997). Although denitrification is not demanded by the Brazilian legislation (CONAMA, 2005), it is absolutely recommendable for all activated sludge systems, because of its economic and operational advantages, such as: lower production of excess sludge, less energy for the aeration, better settling of the sludge and besides of all facts, denitrification can be integrated easily in the activated sludge process, especially in the SBRProcess (ATV-Manual, 1997, Nitrogen Control, 1993). The denitrification capacity of wastewater treatment is always limited by two factors. The first limitation is the $\mathrm{C}(\mathrm{COD})$ : $\mathrm{N}$ (TKN) ratio of the wastewater. A relation of $10 \mathrm{C}$ to $1 \mathrm{~N}$ is considered sufficient for a full denitrification
(ATV-Manual, 1997). On the other hand, a 100\% denitrification is not possible, due to the configuration of activated sludge systems, which is the second limitation. The only way to achieve a $100 \%$ denitrification is a post-denitrification using an artificial carbon source. The most common configuration without carbon source is the predenitrification, where the efficiency of denitrification depends on the volume of return sludge flow:

$\eta_{\mathrm{DN}}=\mathbf{V}_{\mathrm{SR}+\mathrm{RC}} /\left(\mathbf{V}_{\mathrm{SR}+\mathrm{RC}}+\mathbf{1}\right)$

where : $V_{\mathrm{SR}+\mathrm{RC}}=$ Volume of sludge return and sludge recirculation flow (ATV-Manual, 1997).

Another possibility is the cascade denitrification where the efficiency of denitrification depends on the number of cascades.

$\eta_{\mathrm{DN}}=1-\left(\mathbf{1} /\left(\mathbf{n}_{\mathrm{C}}\left(\mathbf{1}+\mathbf{V}_{\mathrm{SR}}\right)\right)\right.$,

where $\quad \mathrm{n}_{\mathrm{C}}=$ number of cascades

$\mathrm{V}_{\mathrm{SR}}=$ Volume of sludge return flow

The alkalinity depends on the relation between bicarbonate and carbonic gas and it is determined by the amount of $\mathrm{HCl}$ necessary to adjust 1 liter of water to a $\mathrm{pH}$ of 4.3 . Depending on the type of carbonate, there are different parameters with different dimensions, as shown in Table 1.

Table 1 - Equivalent parameters of alkalinity: Ks (ATV Manual 1997)

\begin{tabular}{cc}
\hline Parameter of alkalinity & Factor \\
\hline $\mathrm{HCO}_{3}^{-}(\mathrm{mmol} / \mathrm{L})$ & 1 \\
$\mathrm{HCO}_{3}^{-}(\mathrm{mg} / \mathrm{L})$ & $61 \mathrm{mg} / \mathrm{mmol}$ \\
$\mathrm{CaCO}_{3}(\mathrm{mg} / \mathrm{L})$ & $50 \mathrm{mg} / \mathrm{mmol}$ \\
\hline
\end{tabular}

The alkalinity of wastewater results directly of the alkalinity of the drinking water. The ammonification (or TKN hydrolysis) increases the alkalinity of the wastewater:

$$
\mathrm{NTK}+\mathrm{H}_{2} \mathrm{O} \rightarrow \mathrm{NH}_{4}^{+}+\mathrm{OH}^{-}
$$

Von Sperling (1997) mentioned the alkalinity of raw wastewater in Brazil with $110-170 \mathrm{mg}$ $\mathrm{CaCO}_{3} / \mathrm{L}$, (or $2.2-3.4 \mathrm{mmol} \mathrm{HCO}_{3}-/ \mathrm{L}$ ). This is, for example, half of the alkalinity of common wastewater in Germany (ATV manual, 1997). The nitrification process consumes alkalinity; the nitrification of $1 \mathrm{~mol} \mathrm{NH}_{4}-\mathrm{N}$ produces exactly 2 mol of $\mathrm{H}^{+}$:

$\mathrm{NH}_{4}{ }^{+}+2 \mathrm{O}_{2} \rightarrow \mathrm{NO}_{3}^{-}+\mathrm{H}_{2} \mathrm{O}+2 \mathrm{H}^{+}$

The bicarbonate/carbonic gas system reacts in the form:

$$
2 \mathrm{H}^{+}+2 \mathrm{HCO}_{3}^{-} \rightarrow 2 \mathrm{H}_{2} \mathrm{O}+2 \mathrm{CO}_{2}
$$

By this $1 \mathrm{~mol} \mathrm{NH}_{4}^{+}(14 \mathrm{mg} \mathrm{NH}-\mathrm{N} / \mathrm{L})$ uses $2 \mathrm{~mol}$ $\mathrm{HCO}_{3}{ }^{-}$(or $122 \mathrm{mg} \mathrm{HCO}_{3}-/ \mathrm{L}$, or $100 \mathrm{mg} \mathrm{CaCO} / \mathrm{L}$ ), what means that $1 \mathrm{mg} \mathrm{NH} 4_{4}-\mathrm{N} / \mathrm{L}$ consumes 0.14 mmol $\mathrm{HCO}_{3}^{-} / \mathrm{L}\left(7.14 \mathrm{mg} \mathrm{CaCO}_{3} / \mathrm{L}\right)$. As the hydrolysis of the TKN, the denitrification process 
also increases the alkalinity (adapted of the ATV Manual, 1997):

$$
\mathrm{NO}_{3}{ }^{-}+\mathrm{H}^{+} \rightarrow 0.5 \mathrm{~N}_{2}+0.5 \mathrm{H}_{2} \mathrm{O}+2.5(\mathrm{O})
$$

That means that the denitrification of $1 \mathrm{~mol}$ nitrate recuperated $1 \mathrm{~mol} \mathrm{HCO}_{3}$, (or $0.07 \mathrm{mmol} \mathrm{HCO}_{3}{ }^{-} / \mathrm{L}$ or $3.57 \mathrm{mg} \mathrm{CaCO}_{3} / \mathrm{L}$ for $1 \mathrm{mg} \mathrm{NO}_{3}-\mathrm{N} / \mathrm{L}$ ) accurately the half of what was used for the nitrate production.

It can be concluded that the final alkalinity after the biological process in a nitrifying reactor depends on the natural alkalinity (Ks) and the ammonia concentration $\left(\mathrm{NH}_{4}-\mathrm{N}_{\mathrm{o}}\right)$ of the wastewater. The difference between the ammonium concentration of the wastewater $\left(\mathrm{NH}_{4}\right.$ $\mathrm{N}_{\mathrm{o}}$ ) and the treated effluent $\left(\mathrm{NH}_{4}-\mathrm{N}_{\mathrm{e}}\right)$ is the resulting nitrate concentration $\left(\mathrm{NO}_{3}-\mathrm{N}_{\mathrm{e}}\right)$. Considering these facts the calculation for the alkalinity in the effluent $\left(\mathrm{Ks}_{\mathrm{e}}\right)$ follows the equation (Manual ATV 1997):

$$
\begin{aligned}
\mathrm{Ks}_{\mathrm{e}}= & \mathrm{Ks}_{\mathrm{o}}-0.07\left(\mathrm{NH}_{4}-\mathrm{N}_{\mathrm{o}}-\mathrm{NH}_{4}-\mathrm{N}_{\mathrm{e}}+\mathrm{NO}_{3}-\mathrm{N}_{\mathrm{e}}\right) \\
& m \mathrm{HCO}_{3}^{-} / \mathrm{L} \\
\mathbf{K s}_{\mathbf{e}}= & \mathbf{K s}_{\mathbf{0}}-\mathbf{3 . 5 7}\left(\mathbf{N H}_{\mathbf{4}}-\mathbf{N}_{\mathbf{0}}-\mathbf{N H}_{\mathbf{4}}-\mathbf{N}_{\mathbf{e}}+\mathbf{N O}_{\mathbf{3}}-\mathbf{N}_{\mathrm{e}}\right) \\
& \mathbf{m g ~ C a C O} \mathbf{C O}^{-} / \mathbf{L}
\end{aligned}
$$

The concentration of $\mathrm{NH}_{4}-\mathrm{N}$ which is oxidized to $\mathrm{NO}_{3}-\mathrm{N}$ and not reduced (denitrification) has to be considered twice (because $2 \mathrm{~mol} \mathrm{H}^{+}$are produced), while the concentration of $\mathrm{NH}_{4}-\mathrm{N}$, which is oxidized and reduced to $\mathrm{N}_{2}$ gas has to be considered only once (because $1 \mathrm{~mol} \mathrm{H}^{+}$is recuperated). This correlation was used for the evaluation of the alkalinity in system RSB.

The objective of this work was to analyze the potential of denitrification on the stabilization of the activated sludge process operating with wastewater with low alkalinity.

\section{MATERIALS AND METHODS}

\section{SBR pilot reactor and integration of denitrification}

A pilot SBR with volume of $1.3 \mathrm{~m}^{3}$ was situated in the campus of the University (UFSC, Universidade Federal de Santa Catarina). It was operated with wastewater colleted from a public sewer. The wastewater was pretreated in a septic tank with a retention time of 2-3 days. The SBR worked in three cycles a day, each cycle of $8 \mathrm{~h}$, receiving 400L wastewater (1,200 L per day). The operation of a full cycle (charge, aeration, settling and discharge) was totally automatic and in order to reach a efficient denitrification, the charge and aeration was divided in four steps (repeating the charge and aeration four times). Modeled on the well known cascade denitrification process, this SBR filling strategy was called "cascade filling". In order to obtain a total denitrification of resistant nitrate of the sludge (Fig. 1) the first charge of the cycle was larger than the three following $(1 \times 250$ $\mathrm{L}$ and $3 \times 50 \mathrm{~L}$ ).

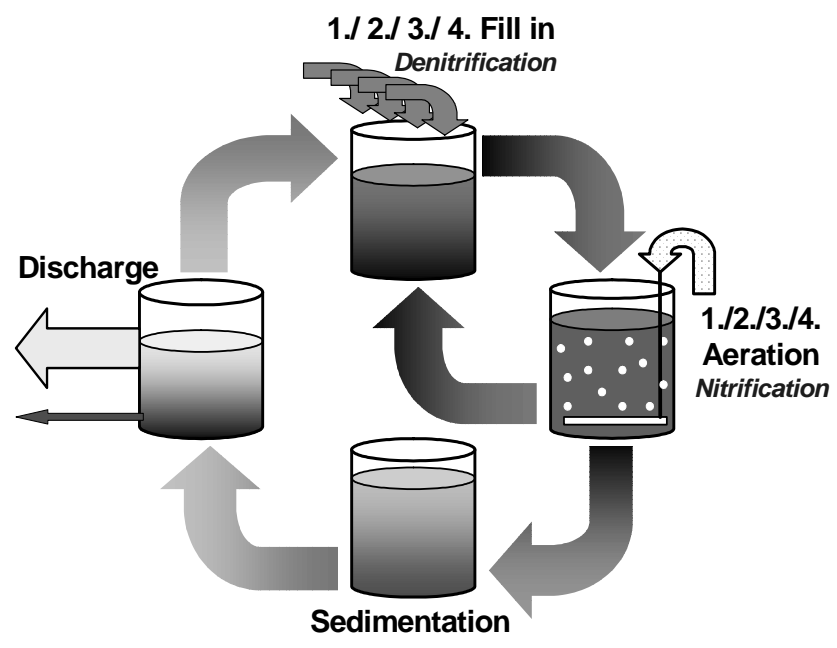

Figure 1: One cycle ( $8 \mathrm{~h})$ of the pilot SBR, working with the idea of cascade filling in four steps 
In order to determine a correlation of alkalinity and denitrification efficiency the following analyses program was carried out:

- Three times per week parameters of influent and effluent: Alkalinity, COD and SS according to the Standard Methods (1998); $\mathrm{NH}_{4^{-}}$ $\mathrm{N}, \quad \mathrm{NO}_{3}-\mathrm{N}, \quad \mathrm{NO}_{2}-\mathrm{N}, \quad \mathrm{PO}_{4}-\mathrm{P}$ with colorimetric method (kit of Merck).

- Once a week a cycle of $8 \mathrm{~h}$ was analyzed, with control of $\mathrm{pH}, \mathrm{O}_{2}$ and temperature and sampling at the end of the anoxic and aerobic phases (sample of filtered sludge) for analyses of: $\mathrm{COD}, \mathrm{NH}_{4}-\mathrm{N}$, $\mathrm{NO}_{3}-\mathrm{N}, \mathrm{NO}_{2}-\mathrm{N}$, and alkalinity.

- $\mathrm{SVI}_{30}$ (Sludge Volume Index) and microscopy analyses of the activated sludge were carried out once a week. After the first negative experiences with low $\mathrm{pH}$ values, for $\mathrm{pH}$ values below 7.0 lime was added. Approximately $50 \mathrm{~g}$ of lime per week were used to keep $\mathrm{pH}$ around 7.0.

\section{Denitrification efficiency}

According to Fig. 1 in the SBR process with the principle of cascade filling, theoretically only the volume of the last filling can't be denitrified, that means a denitrification efficiency of :

$\eta_{\mathrm{DN}}=\mathbf{1}-\left(\left(\mathbf{V}_{\text {feed }} / \mathbf{V}_{\text {last step }}\right)\right.$

where $\mathrm{V}_{\text {feed }} \quad=$ Volume of total cycle filling $\mathrm{V}_{\text {last step }}=$ Volume of last step filling

The pilot SBR with filling in four steps (350L :

$50 \mathrm{~L})$ would have a theoretically maximum denitrification efficiency of $87.5 \%$.

\section{RESULTS AND DISCUSSION}

\section{Operation of the pilot SBR}

Nitrification started a week after the inoculation of the pilot reactor with activated sludge. After five weeks and temperatures around $20-25^{\circ} \mathrm{C}$, the nitrification process was stabilized with effluent concentrations below $1 \mathrm{mg} \mathrm{NH}$-N/L. Probably the relatively long stabilization time was due to the low $\mathrm{pH}$ and other inhibitory factors. Without limewater addition, it was observed that:

Between a pH of $6.8-6.0$ the protozoa's disappeared. The last surviving organisms were amoebae (Fig. 2A)

Below 6.5 the activated sludge flocs started to disintegrate (deflocculation), resulting in turbid effluent and enhanced bacterial loss

Between $\mathrm{pH}$ of $6.2-6.0$ the nitrification was affected and an intensive growth of fingered and amorphous zoogleal organisms was observed (Fig. 2B).

Filamentous bacteria (Fig. 2D), like type $021 \mathrm{~N}$ and sulfur bacteria (Jenkins et al., 1993) were observed during all the operation. This organism contributed to an increasing $\mathrm{SVI}_{30}$ (Sludge Volume Index), which increased from 120 to $180 \mathrm{~mL} / \mathrm{g}$, indicating bulking sludge and sedimentation problems.

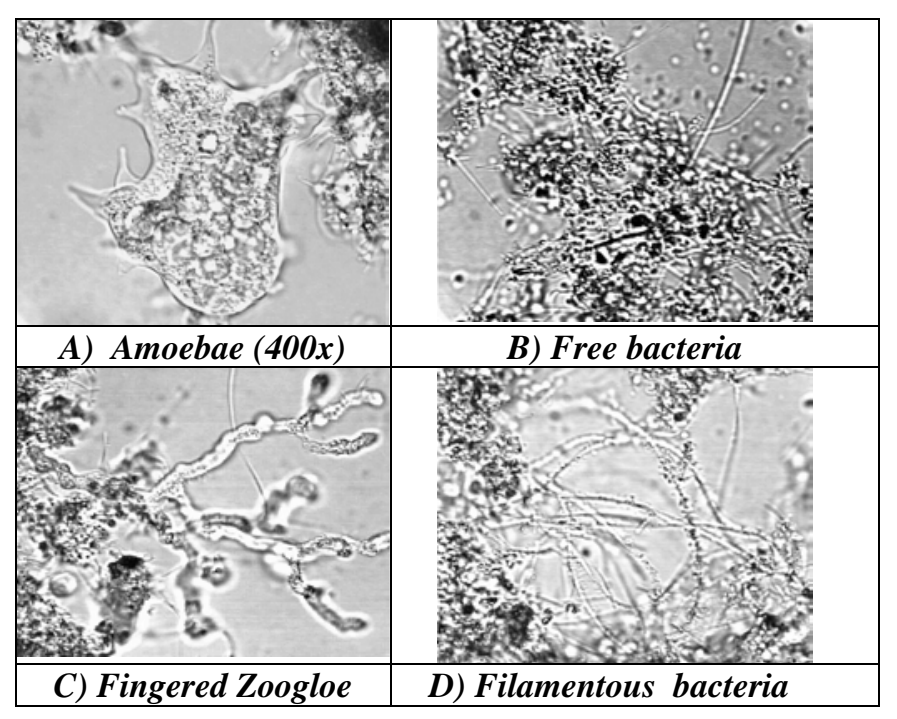

Figure 2 - Microscopic analyses to detect floc formation problems in operation phases 
The most important objective of further investigations was the improvement of denitrification until the theoretical technical limitation of $87.5 \%$ (equation 9) to keep the $\mathrm{pH}$ constant without addition of lime. But the results showed that the denitrification was limited by the low $\mathrm{COD} / \mathrm{BOD}_{5}$ concentration (low $\mathrm{C} / \mathrm{N}$ ratio), reported also by Hoffmann et al (2004). Fig. 3A shows one of the first cycle results, done at the beginning of nitrification stabilization $\left(4^{\text {th }}\right.$ week). The cycle in Fig. 3B was obtained two months later, accidentally a day with high COD concentration in wastewater.

Fig. 3A shows the same nitrification velocity in all the four aerated nitrification phases. The denitrification velocity was higher in the first anoxic phase with the higher organic load (250L wastewater) and decreased in the three following anoxic phases with load of 50L wastewater.
Although the denitrification seemed to have a high efficiency, nitrate concentration at the end of the cycle was higher than in the beginning. Sometimes nitrate concentration increased up to $20 \mathrm{mg} \mathrm{NO}_{3^{-}}$ N/L (Table 2).

The wastewater in Fig. 3B had a higher COD/N ratio. At first high loading phase, an efficient denitrification process was observed and at subsequent following phases, the denitrification was lower, but the cycle resulted in lower nitrate concentration than at the beginning. The problem in example 3B was the nitrification. To improve the denitrification, the aeration was reduced to guarantee the total absence of oxygen during the anoxic phases, as shown in the second diagram. With uncommonly high organic load of the wastewater, this aeration was not sufficient for total nitrification; the nitrification was limited by the oxygen lack.

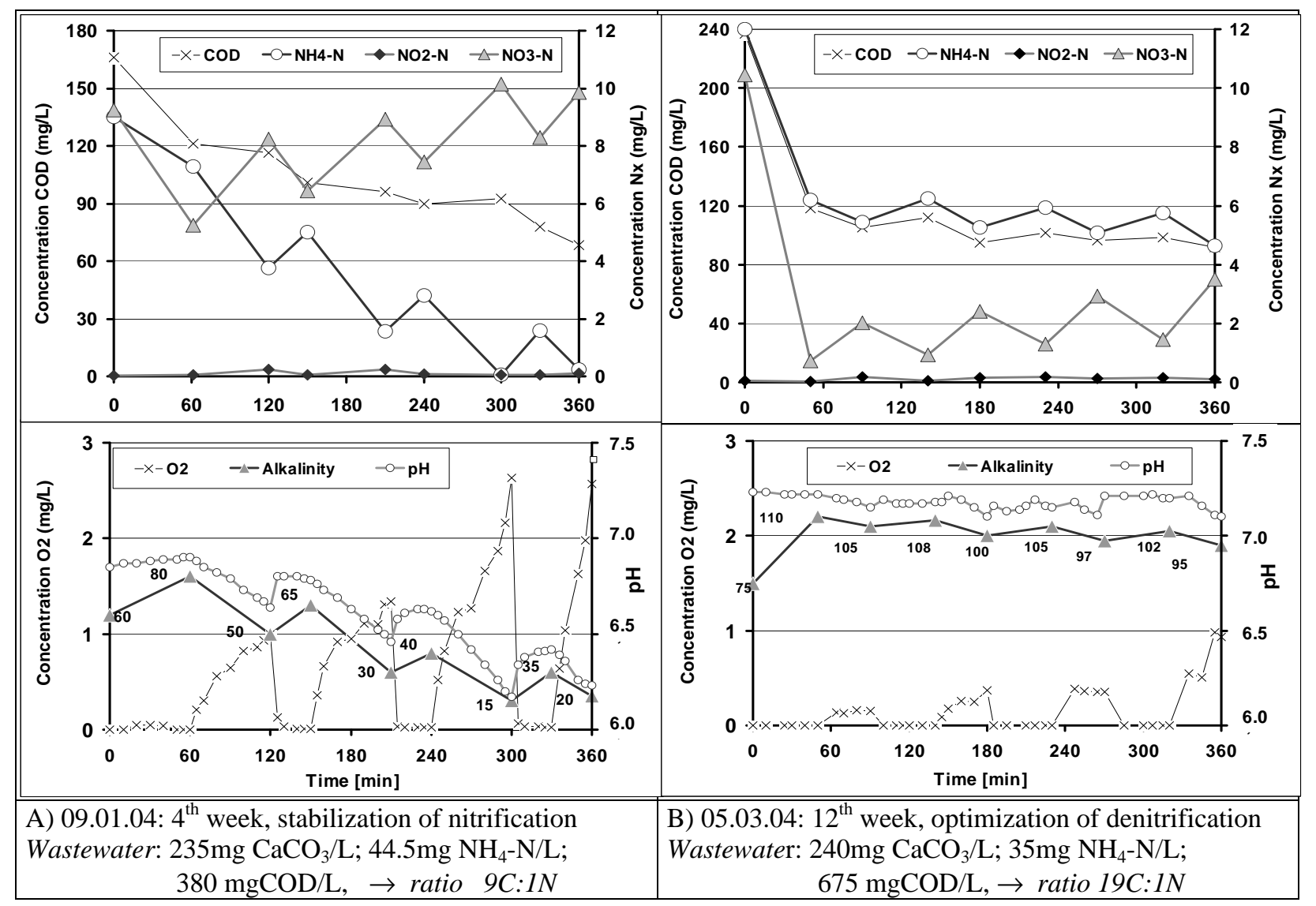

Figure 3 - Results of monitoring of 2 cycles of $8 \mathrm{~h}$ ( $6 \mathrm{~h}$ denitrification and nitrification, $1 \mathrm{~h}$ sedimentation and $1 \mathrm{~h}$ for removing of treated wastewater)

Also, the alkalinity and the $\mathrm{pH}$ were analyzed,

(Fig. 3). For better visualization, the alkalinity in 
$3 \mathrm{~A}$ and $3 \mathrm{~B}$ was calculated in mmol $\mathrm{HCO}_{3}-/ \mathrm{L}$ (Table 1), the more common unit in Brazil being $\mathrm{mg} \mathrm{CaCO}_{3} / \mathrm{L}$, which was noted in the Figure.

In Fig. 3A, the two parameters showed high alterations, $\mathrm{pH}$ and alkalinity increase clearly in the anoxic filling phase and decrease during the nitrification. As a result of the first nitrification phase, the alkalinity reduced to the recommended value for operation stability of $75 \mathrm{mg} \mathrm{CaCO}_{3} / \mathrm{L}$. This cycle finished with $20 \mathrm{mg} \mathrm{CaCO}_{3} / \mathrm{L}$. Alterations of this type characterized a wastewater with an insufficient natural alkalinity.

Fig. 3B did not show these high alterations of $\mathrm{pH}$ and alkalinity, whereas the alkalinity of the wastewater was nearly the same. The lower nitrification activity (lower concentration of $\mathrm{NH}_{4}$ $\mathrm{N}_{0}$ in the wastewater as well as higher concentration of $\mathrm{NH}_{4}-\mathrm{N}_{\mathrm{e}}$ in the effluent) and the strong increase of alkalinity in the first denitrification phase resulted in a stabilization of $\mathrm{pH}$ and in an alkalinity value above $75 \mathrm{mg}$ $\mathrm{CaCO}_{3} / \mathrm{L}$ during the whole operation cycle.

\section{Correlation between Nitrification, Alkalinity and Denitrification}

The results of all of the monitoring cycles of the pilot SBR were analyzed through the equation 9, which calculated the theoretical alkalinity after nitrification and denitrification. The objective was to compare analytical results and the theoretical values. Table 2 shows the results of the analyses and calculation during three months of operation.After the anaerobic pretreatment in the septic tank, the wastewater showed an average alkalinity of $234 \mathrm{mg} \mathrm{CaCO}_{3} / \mathrm{L}$, with a minimum of $185 \mathrm{mg} \mathrm{CaCO} / \mathrm{L}$ and a maximum of $275 \mathrm{mg}$ $\mathrm{CaCO}_{3} / \mathrm{L}$ and a $\mathrm{pH}$ value of 7.0. The COD concentration in wastewater showed a variation between 253 and $673 \mathrm{mg} \mathrm{COD} / \mathrm{L}$, ammonia concentrations between 25.5 and $44.4 \mathrm{mg} \mathrm{NH}$ N- $^{-}$ $\mathrm{N} / \mathrm{L}$, resulting in an average COD : $\mathrm{N}$ ration of about 10:1 but it is a well known fact that not the whole COD was available for denitrification. The treated effluent showed:

A concentration of $79 \mathrm{mg} \mathrm{COD} / \mathrm{L}$ as non degradable COD in this process with a sludge age of 25 days.
An almost complete nitrification was achieved. Some times the higher ammonia effluent concentrations were provoked by an insufficient aeration.

The average denitrification efficiency was about $65 \%$, with nitrate concentration in the treated effluent of $12.8 \mathrm{mg} \mathrm{NO}_{3}$-N/L (Table 2).

Even on days with higher denitrification rates, as the day 09/01/04 (Table 2 and Fig. 3A) with 78\% denitrification, a decreasing alkalinity during the cycle was observed, due to the total nitrification of the wastewater with high ammonia concentration (44.5 mg $\left.\mathrm{NH}_{4}-\mathrm{N}\right)$ and low alkalinity (235 $\left.\mathrm{CaCO}_{3} / \mathrm{L}\right)$ on this day. The days with high alkalinity and low ammonia concentration, for example at days 05/03, 07/03, 11/03, 14/03, 16/03 and 18/03/04 the alkalinity in the reactor was kept above $75 \mathrm{mg} \mathrm{CaCO}_{3} / \mathrm{L}$, which was the limit for stable operation. In most of the days, the alkalinity of the treated wastewater was below this limit at the end of the process (Table 2).

The last column shows the result of the calculation of the value of theoretical alkalinity at the end of the process ( $\mathrm{Ks}_{\mathrm{e}_{\mathrm{e}}}$, given in equation 8$)$. A good correlation between the real and theoretical value was observed, even if 5\% higher values were analyzed with calculation. The reduced alkalinity in the real treatment could be explained for example by the formation of organic acids and $\mathrm{H}_{2} \mathrm{~S}$ in the septic tank. Analyses showed concentrations up to $50 \mathrm{mg} \mathrm{H}_{2} \mathrm{~S} / \mathrm{L}$ in the effluent of septic tank. In one case presence of filamentous sulfur bacteria was also noted in the activated sludge system (Fig. 2D) which oxidized sulfite $\left(\mathrm{S}_{2}{ }^{-}\right)$in the aerobic phase to sulfate $\left(\mathrm{SO}_{4}{ }^{2-}\right)$ (Jenkins et al. 1997).

Despite this temporary problem, there were cycles with good accordance between the calculated and analyzed value of alkalinity, as on the days $21 / 01$, $5 / 02,11 / 02,13 / 02,20 / 02,25 / 02,01 / 03,13 / 03$, $14 / 03,18 / 03,19 / 03$ and 20/03.

As conclusion to this result, equation 8 was used to develop a diagram that determined the necessity of denitrification, depending on the ammonia concentration and the alkalinity of wastewater with the objective to keep the alkalinity in the activated sludge and effluent above $75 \mathrm{mmol}$ $\mathrm{CaCO}_{3} / \mathrm{l}$. 
Table 2 - Characterization of influent and effluent wastewater of the pilot SBR and comparison of the calculated alkalinity with the real alkalinity

\begin{tabular}{|c|c|c|c|c|c|c|c|c|c|c|}
\hline & \multicolumn{4}{|c|}{ Effluent of the Septic Tank (0) } & \multicolumn{5}{|c|}{ Effluent of the Activated Sludge SBR (e) } & \multirow{2}{*}{$\begin{array}{l}\text { Calculation } \\
\text { Alkalinity }_{\mathrm{e}} \\
\end{array}$} \\
\hline & $\mathrm{COD}_{0}$ & $\mathrm{NH}_{4}-\mathrm{N}_{0}$ & $\mathrm{pH}_{0}$ & Alkalinity $_{0}$ & $\mathrm{COD}_{\mathrm{e}}$ & $\mathrm{NH}_{4}-\mathrm{N}_{\mathrm{e}}$ & $\mathrm{NO}_{3}-\mathrm{N}_{\mathrm{e}}$ & $\mathbf{p H}_{\mathrm{e}}$ & Alkalinity $_{\mathrm{e}}$ & \\
\hline & $\mathbf{m g} / \mathbf{L}$ & $\mathrm{mg} / \mathrm{L}$ & & $\begin{array}{l}\mathrm{mg} \\
\mathrm{CaCO}_{3} / \mathrm{L}\end{array}$ & $\mathbf{m g} / \mathbf{L}$ & $\mathrm{mg} / \mathrm{L}$ & $\mathrm{mg} / \mathrm{L}$ & & $\begin{array}{l}\mathrm{mg} \\
\mathrm{CaCO}_{3} / \mathrm{L}\end{array}$ & $\begin{array}{l}\mathrm{mg} \\
\mathrm{CaCO}_{3} / \mathrm{L}\end{array}$ \\
\hline 01.06 .04 & 253 & 39.2 & 6.9 & 225 & 68 & 0.0 & 6.8 & 6.8 & 38 & 61.1 \\
\hline 01.08 .04 & 261 & 41.7 & 7.0 & 235 & 52 & 0.4 & 6.1 & 7.0 & 45 & 65.8 \\
\hline 01.09 .04 & 380 & 44.5 & 6.9 & 235 & 102 & 0.3 & 9.8 & 6.2 & 20 & 42.0 \\
\hline 01.10 .04 & 255 & 33.5 & 6.8 & 195 & 57 & 0.0 & 11.2 & 6.6 & 25 & 35.6 \\
\hline 01.12 .04 & 253 & 39.9 & - & 225 & 47 & 0.0 & 10.5 & 6.5 & 18 & 45.3 \\
\hline 01.21 .04 & 349 & 40.2 & 6.9 & 265 & - & 0.0 & 16.8 & 7.0 & 65 & 61.5 \\
\hline 01.23 .04 & 334 & 38.9 & 6.9 & 245 & 86 & 0.6 & 12.1 & 6.4 & 25 & 65.1 \\
\hline 02.03 .04 & 383 & 31.2 & 7.1 & 225 & 94 & 0.1 & 20.2 & 6.4 & 18 & 41.6 \\
\hline 02.05 .04 & 430 & 32.9 & - & 210 & 96 & 0.0 & 15.8 & 6.6 & 33 & 36.3 \\
\hline 02.06 .04 & 315 & 35.3 & 7.0 & 215 & 96 & 0.0 & 20.5 & 6.8 & 25 & 16.0 \\
\hline 02.11 .04 & 348 & 42.0 & - & 255 & 90 & 0.0 & 5.2 & 7.2 & 108 & 86.4 \\
\hline 02.13 .04 & 258 & 42.9 & 7.1 & 250 & 53 & 0.0 & 19.3 & 6.4 & 35 & 27.9 \\
\hline 02.18 .04 & 449 & 39.7 & 6.9 & 240 & 73 & 1.0 & 9.7 & 7.0 & 60 & 67.2 \\
\hline 02.20 .04 & 572 & 41.2 & 7.2 & 255 & 96 & 2.9 & 15.4 & 6.6 & 53 & 63.4 \\
\hline 02.22 .04 & 454 & 36.5 & 6.8 & 225 & 101 & 2.8 & 16.6 & 6.7 & 55 & 45.5 \\
\hline 02.25 .04 & 389 & 37.6 & 7.0 & 235 & 74 & 0.0 & 19.3 & 6.8 & 33 & 31.8 \\
\hline 02.27 .04 & 391 & 37.9 & 6.9 & 220 & 91 & 0.0 & 16.6 & 6.9 & 40 & 25.4 \\
\hline 03.01 .04 & 355 & 25.5 & 6.7 & 185 & 86 & 0.0 & 16.8 & 6.9 & 33 & 34.0 \\
\hline 03.03 .04 & 431 & 38.0 & 6.8 & 230 & 91 & 1.7 & 11.3 & 7.0 & 70 & 60.3 \\
\hline 03.05 .04 & 675 & 35.3 & 7.1 & 240 & 91 & 4.7 & 3.5 & 7.1 & 95 & 118.4 \\
\hline 03.07 .04 & 640 & 36.9 & 7.0 & 240 & - & 6.2 & 3.2 & 7.3 & 90 & 119.0 \\
\hline 03.11 .04 & 493 & 35.4 & - & 255 & 92 & 0.0 & 20.6 & 7.2 & 85 & 55.0 \\
\hline 03.13 .04 & 423 & 39.0 & 7.2 & 230 & 86 & 0.0 & 15.8 & 6.9 & 63 & 34.4 \\
\hline 03.14 .04 & 465 & 35.6 & 7.0 & 245 & 75 & 0.0 & 9.3 & 7.0 & 75 & 85.1 \\
\hline 03.16 .04 & 398 & 36.3 & 6.9 & 240 & 78 & 0.1 & 10.8 & 7.1 & 100 & 72.4 \\
\hline 03.18 .04 & 391 & 34.2 & 7.1 & 250 & 55 & 0.1 & 9.0 & 7.1 & 105 & 96.1 \\
\hline 03.19 .04 & 385 & 36.3 & 7.0 & 240 & 68 & 0.0 & 11.0 & 6.9 & 68 & 71.1 \\
\hline 03.20 .04 & 350 & 39.6 & 7.2 & 250 & 65 & 0.0 & 16.0 & 6.9 & 65 & 51.5 \\
\hline Average & 396 & 37.4 & 7.0 & 234 & 79 & 0.7 & 12.8 & 6.8 & 55.1 & 57.7 \\
\hline
\end{tabular}

It was calculated $100 \%$ nitrification $(100 \%$ oxidation of ammonia-N to nitrate-N), as it was normal for dimensioning of wastewater treatment2 plant. Fig. 4 shows the result of the calculation. The area below the line "without DN" was characterized by such an high ammonia to alkalinity ratio that did not need denitrification for alkalinity recuperation. The area above the line "100\% DN" characterized the area where the correlation between ammonia concentration and $\mathbf{3}$ alkalinity was limited and even in case of $100 \%$ denitrification the alkalinity would be reduced below $75 \mathrm{mg} \mathrm{CaCO}_{3} / \mathrm{L}$. However, a denitrification of $100 \%$ only could be reached with a postdenitrification by an additional carbon source. The denitrification rates between these two limits (20, 40, 60 and $80 \%$ ) determined the possibility to keep the alkalinity and $\mathrm{pH}$ (Fig. 4):

1 Example 1: The wastewater in case of the investigated pilot SBR with $235 \mathrm{mg} \mathrm{CaCO}_{3} / \mathrm{L}$ (Table 2) would not need any denitrification until a nitrification of $22 \mathrm{mg} \quad \mathrm{NH}_{4}-\mathrm{N} / \mathrm{L}$. The denitrification of $65 \%$ would be sufficient to neutralize the acid, produced as a result of nitrification of $32 \mathrm{mg} \mathrm{NH}_{4}-\mathrm{N}$ in the influent wastewater.

Example 2: In reality the pilot plant had to nitrify on average $\mathbf{3 7 . 4} \mathbf{~ m g ~} \mathbf{N H}_{\mathbf{4}}-\mathbf{N} / \mathbf{L}$, (Table 2) this would need about $80 \%$ denitrification with the given alkalinity of $235 \mathrm{CaCO}_{3} / \mathrm{L}$ (example 1). With the realized denitrification of $65 \%$, an alkalinity of approximately $260 \mathrm{CaCO}_{3} / \mathrm{L}$ would be necessary to stabilize the operation.

Example 3: According Von Sperling (1997), an alkalinity of $170 \mathrm{mg} \mathrm{CaCO}_{3} / \mathrm{L}$ is normal in the Brazilian wastewater. Corresponding to the calculation, a nitrification of only $20 \mathrm{mg} \mathrm{NH}_{4}-\mathrm{N} / \mathrm{L}$, for example, would require a $60 \%$ denitrification to stabilize the $\mathrm{pH}$. With concentrations above $30 \mathrm{mg} \quad \mathrm{NH}_{4}-\mathrm{N} / \mathrm{L}$, no denitrification could prevent the necessity of lime water to stabilize the operation. 


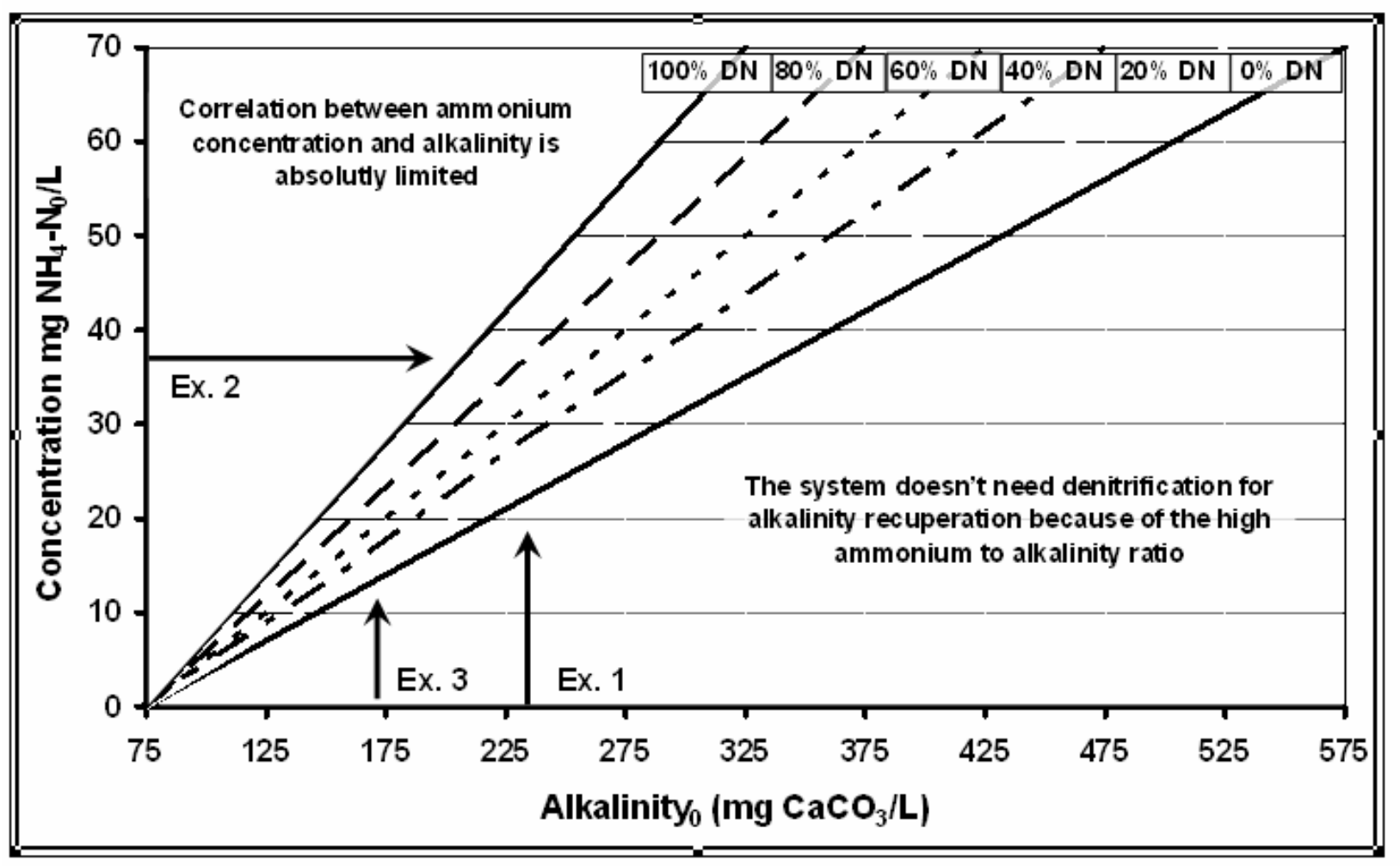

Figure 4 - Prognostic diagram for the denitrification necessity, resulting of the necessity to keep the alkalinity in the rector above of $75 \mathrm{mg} \mathrm{CaCO}_{3} / \mathrm{L}$

\section{CONCLUSION}

The results obtained with an activated sludge of a pilot SBR showed that decreasing values of $\mathrm{pH}$, provoked by acid formation during the nitrification have negative effects of process stability, destruction of activated sludge flocs was observed and the loss of active biomass. Alkalinity of more than $75 \mathrm{mg} \mathrm{CaCO} / / \mathrm{L}$ could prevent the rise of $\mathrm{pH}$ during the operation. The wastewater with the average alkalinity of 234 mg $\mathrm{CaCO}_{3} / \mathrm{L}$ and ammonium concentration of $37 \mathrm{mg} \mathrm{NH}_{4}-\mathrm{N} / \mathrm{L}$ did not have a sufficient natural alkalinity to keep up the $\mathrm{pH}$ during the nitrification process. The presented diagram showed that a constant denitrification of at least $80 \%$ would be necessary to keep up the $\mathrm{pH}$. This would be the absolute maximum for a denitrification without external carbon sources. In the pilot SBR with the principle of cascade filling in three steps, a denitrification of $87 \%$ was calculated as theoretically possible, but with the given wastewater only a denitrification of $65 \%$ was realized, due to the relatively low C:N ratio. The monitoring of the different cycles showed clearly an influence of the concentration of $\mathrm{COD} / \mathrm{BOD}_{5}$ in the wastewater. Due to the pretreatment in a septic tank the concentration of $\mathrm{COD} / \mathrm{BOD}_{5}$ was relatively low and the $\mathrm{H}_{2} \mathrm{~S}$, formed in the anaerobic pretreatment process, influenced the alkalinity. It could be very likely that operational problems caused by the low $\mathrm{pH}$ and the low alkalinity periodically happened in most of aerobic treatment plants in Brazil, which always would result in a low efficiency of the biological process. The $\mathrm{pH}$ could be increased for example by lime or lime water addition, but the most economic solution consisted in the controlled improvement of denitrification, a process which could recovery $50 \%$ of the lost alkalinity by nitrification. The experiences with the pilot reactor proved that the denitrification 
increased the $\mathrm{pH}$ significantly and hence, it was a secure way to prevent operational problems. It could save energy and produce lower sludge excess volume in activated sludge systems.

\section{ACKNOWLEDGEMENTS}

We thank to the CAPES and to the CNPq for the concession of grants, and to the German foundation "Oswald Schulze" and Rotária do Brasil Ltda. for the equipment supply.

\section{RESUMO}

Os problemas provocados pela nitrificação no esgoto com baixa alcalinidade foram analisados num reator piloto do tipo lodos ativados seqüencial por batelada (RSB), alimentado por esgoto urbano. A diminuição do $\mathrm{pH}$ se mostrou em três níveis: com $\mathrm{pH}$ de 6,8 - 6,0 os protozoários, responsáveis para a filtração da fase liquida, desaparecerem; os flocos de lodos ativados começaram a se destruir abaixo $\mathrm{pH}$ 6,5 resultando em elevação da turbidez no efluente final e abaixo de $\mathrm{pH}$ 6,2-6,0 a nitrificação foi afetada. A influência da desnitrificação para manter o $\mathrm{pH}$ foi analisada.

Devido a baixa relação $\mathrm{C}: \mathrm{N}$ no esgoto prétratado, a desnitrificação não se mostrou suficiente para manter o $\mathrm{pH}$ estável. Este trabalho apresenta o cálculo da alcalinidade que considera a influência da nitrificação e desnitrificação, de acordo com os resultados obtidos no RSB. Baseado nesse cálculo, foi desenvolvida uma recomendação na forma gráfica para usar em ETE’s afetadas por baixa alcalinidade.

\section{REFERENCES}

ATV Manual (1997). ATV Handbuch Biologische und Weitergehende Abwassereinigung 4. Auflage 1997, Ernst and Sohn, Berlin, ATV, Hennef (Germany).

CONAMA (2005): Conselho Nacional do Meio Ambiente, Resolução $\mathrm{N}^{\circ} 357$, de 17 de março de 2005.

Hoffmann, H; Wolff; D.B.; Costa; T.B.; Weitz J.; Platzer, C.; Costa, R.H.R. (2004): Avaliação de Reatores Seqüenciais por Batelada do Tipo Lodo Ativado como Sistemas Descentralizados para a Remoção de Nutrientes, in IV Simpósio Internacional de Qualidade Ambiental, Porto Alegre. [CDROM].

Jenkins, D.; Richard, G.R.; Glen, T.D (1993): Manual on the causes and control of activated sludge bulking and foaming, $2^{\text {nd }}$ Ed., Lewis Publishers Inc.

Nitrogen Control-EPA Manual (1993). Technomic Publishing, Pennsylvania, USA.

Standard Methods for the Examination of Water and Wastewater (1998) 20 ${ }^{\text {th }}$ Ed. APHA, AWWA, WEF. Washington, DC, USA.

Wolff, D.; Ochoa, J.C.; Paul, E.; Costa, R.H.R. (2005) Nitrification in Hybrid Reactor with a Recycled Plastic Support Material. Brazilian Archives of Biology and Technology, 48: Special n, 243-248.

Von Sperling, M. (1997) Lodos Ativados. Belo Horizonte: Departamento de Engenharia Sanitária e Ambiental, UFMG. 
PÁGINA

EM

BRANCO 